\title{
PHARMACOECONOMIC IMPLICATIONS GENERATED BY PRIMARY OPEN-ANGLE GLAUCOMA ON WORKERS
}

\author{
Zoran Velkovski ${ }^{1}$, Maja Belevska², Emilija Gjosevska Dastevska ${ }^{3,4}$
}

\begin{abstract}
Glaucoma is an optic neuropathy which due to the irreversible loss of visual acuity, the direct and consequential costs associated with the treatment and the indirect losses because of the reduced productivity generates social and pharmacoeconomic burdens. The study was designed to assess pharmacoeconomic implications generated by primary open-angle glaucoma on workers. It is a cross sectional study, which included 190 male and female respondents with primary glaucoma, aged 28-67, with visual acuity $>6 / 18(0.33)$, according to the ICD-10 classification, conducted in the period August-November 2020 in North Macedonia. Thirty-four point twenty one percent of the respondents received low income, $40.53 \%$ average and $25.26 \%$, high income. Pharmacological costs for treatment of binocular glaucoma amounted to 24.1-45.4 Euros per month, which accounted for $10.26-19.32 \%$ of the respondents' low income and $<4.82-9.08 \%$ of the respondents' high income. In $21.05 \%$ the economic burden resulted in existential crisis for the family and $25.79 \%$ of the respondents were treated inadequately with generic alternative medicine or inadequate doses of medication due to financial reasons. Loss of productivity was registered in $25.79 \%$ of the respondents, while $21.58 \%$ of whom, due to their inability to carry out the essential work duties, received lower monthly income. Glaucoma generates a huge pharmacoeconomic burden, which is a consequence of direct and other medical costs for treatment and indirect losses from productivity, which requires the use of screening programs for timely diagnosis and adequate regular treatment, which will help maintain visual acuity and work ability, thus reducing the pharmacoeconomic burden.
\end{abstract}

Acta Medica Medianae 2021;60(3):11-19.

Key words: primary glaucoma, pharmacoeconomic implications, treatment, costs, productivity losses

\footnotetext{
${ }^{1}$ Clinical Hospital Bitola, Department of Laboratory Diagnostics, Bitola, North Macedonia

${ }^{2}$ Clinical Hospital Bitola, Department of Ophthalmology, Bitola, North Macedonia

${ }^{3}$ Faculty of Medicine Skopje, Clinic for Eye Diseases, Skopje, North Macedonia

${ }^{4}$ Clinic for Eye Diseases, Skopje, North Macedonia
}

Contact: Zoran Velkovski

Partizanska bb, 7000 Bitola, North Macedonia

E-mail: zoranv_mk@yahoo.com

\section{Introduction}

Glaucoma is a heterogeneous group of diseases of various etiologies characterized by damage to the papilla of the optic nerve, specific defects in the visual field and progressive and irreversible loss of vision $(1,2,3)$.
Glaucoma is classified into congenital, secondary and primary $(4,5)$, and based on the width of the ventricular angle in the anterior chamber, primary glaucoma is divided into primary open-angle glaucoma, which accounts for more than $75 \%$ of all primary glaucoma and closed-angle primary glaucoma $(6,7)$.

Glaucoma, after cataract, is the second most common cause of global blindness in the population, which accounts for $13-18 \%$ of all cases of global blindness; it affects $1-2 \%$ of the population and is characterized by chronic progression and long asymptomatic period due to which, in addition to the diagnosed, there are more than $60 \%$ of undiagnosed cases of the disease $(8,9)$.

Due to the chronic, progressive, long asymptomatic period and nonspecific clinical symptoms in the initial stage, glaucoma is most commonly diagnosed after the age of 40 and has a particularly high frequency over the age of 60 , in both male and female; consequently $50-55 \%$ of all glaucoma cases are female, while in primary closed-angle glaucoma, female patients predominate by $70 \%$ of the overall cases $(9,10)$. 
The economic burden of glaucoma is a consequence of direct medical costs, other direct costs associated with treatment and indirect losses resulting from decreased work ability, reduced income due to productivity losses and increased treatment costs originating from the lifelong treatment of glaucoma. Direct medical costs include: the costs for diagnostics and outpatient treatment, medication, laser therapy, surgery, hospital treatment and other medical procedures during the treatment $(11,12)$.

The pharmacoeconomic costs of the treatment with medications arise not only from their long-term, most often lifelong, use and price, but they also depend on whether the patients receive prescription or over-the-counter medications, i.e. how much the use of these medications is cofinanced by the health insurance funds. There are different co-financing criteria in every country, while in RNM the medications are covered by $0-80 \%(13$, 14, 15).

Other direct costs associated with the treatment of glaucoma include the costs of transporting patients to work and accompanying them to medical examinations, procurement of medications, eye and tactile aids, tuition for learning the Morse code, computer skills, IT and audio information technology, costs for escorts, care and assistance in daily activities, costs for accommodation in nursing homes, etc. $(16,17,18,19)$.

Indirect losses are an additional economic burden resulting from the imbalance between the reduced income, productivity losses and the increased costs, which are a consequence of the health condition caused by the visual impairment to which patients are exposed, and can be individual and social $(11,20)$.

Individual indirect losses can originate from various economic indicators such as reduced income due to early retirement and productivity losses due to decreased work ability (WAI - Work Ability Index), absence from work due to sick leave, reduced income during a period with lower health status adopted to the disability (Disability-Adjusted Life Years/DALYs), etc. $(16,17,21,22)$.

\section{The aim of the study}

The study was designed to identify the pharmacological and economic implications generated by primary open-angle glaucoma on employed workers.

\section{Materials and methods}

It is a cross sectional study with a quantitative analytical approach conducted in the period August-November 2020 on the territory of North Macedonia, which includes 190 employed workers, male and female respondents with primary glaucoma, aged 20-67.

The research was conducted using respondents' clinical history and appropriate, custom designed surveys, while the patients' diagnosis was confirmed by an ophthalmological examination and accompanying medical history. The research was carried out during the periodic systematic examinations of the respondents, who had different educational and professional background, during which the level of their visual impairment was determined according to the ICD 10 classification and it ranged from 0.7 to 0.3 . All respondents were diagnosed with primary open-angle glaucoma at different clinical stages, with the disease progressing over a period from 2 to 20 years.

The research covered various socio-pharmacological and economic indicators: gender, age, clinical stage of the disease, method of therapy, type of prescribed medications, medication and medical procedure costs, monthly costs for treatment, personal income and the impact of the monthly costs on the personal budget, indirect losses due to decreased productivity, analysis of the consequences caused by non-fulfillment or poor performance of commitments with reduced personal income, assessment of the family burden and economic consequences in relation to an inadequate treatment due to economic reasons and other parameters.

The statistical data processing was performed using descriptive and comparative statistical procedures. In addition, statistical programs such as statistics for Windows 7.0 and SPSS 17.0 were also used.

Pearson Chi-Square test for homogeneity was used to determine the differences in the attributive values of dichotomous features (variables) in male and female respondents, while the non-parametric Mann-Whitney $U$ test was used to test the significance of the differences in the independent features (variables). To assess the statistical significance, a level of significance is determined $p<0.05$. The obtained results are presented numerically and in a table.

\section{Results}

The study included 190 respondents with primary angle-angle glaucoma, aged 20-67, of whom $88(16.32 \%)$ were male and $102(53.68 \%)$ were female. They were organized into 3 age groups, 2050, 51-60 and 61-67 (Table 1).

Of the total 190 respondents, $88(46.32 \%)$ were male and $102(53.68 \%)$ were female. Of these, $36(18.95 \%)$ were up to 50 years of age, 79 $(41.58 \%)$ were aged $51-60$ and $75(39.47 \%)$ aged 61-67. The statistical analysis showed that there was no significant difference between the two genders in terms of age structure (Pearson Chi-Square $=5.24943, \mathrm{df}=2, \mathrm{p}=0.072465)$.

A descriptive analysis was also carried out on the individual age of all respondents involved in the study (Table 2).

The average age of the male respondents who participated in the study was 58.05, SD 6.143, median 59, minimum age 44 and maximum age 67, while the average age of the female respondents was 57.63 , SD 6.658 , median 59, minimum age 44 and maximum age 67. 
The statistical analysis showed that there was no significant difference between the two genders in terms of age (Mann-Whitney U Test: $Z=0.262557$ $\mathrm{p}=0.792892)$.

The respondents who were included in this scientific study, depending on the clinical stage in which they were diagnosed with glaucoma, used medical therapy for a period of 1-20 years and the analysis of this parameter is shown in Table 3.

Table 1. Division of respondents according to age groups

\begin{tabular}{|c|c||c|c||c||}
\hline \hline \multicolumn{2}{||c||}{ Age group } & \multicolumn{2}{c||}{ Gender } & \multirow{2}{*}{ Total } \\
\cline { 2 - 5 } Age 20-50 & Number & 15 & 21 & 36 \\
\cline { 2 - 5 } & $\%$ & 7.90 & 11.05 & 18.95 \\
\hline \hline \multirow{2}{*}{ Age 51-60 } & Number & 39 & 40 & 79 \\
\cline { 2 - 5 } & $\%$ & 20.53 & 21.05 & 41.58 \\
\hline \hline \multirow{2}{*}{ Age 61-67 } & Number & 34 & 41 & 75 \\
\cline { 2 - 5 } & $\%$ & 17.89 & 21.58 & 39.47 \\
\hline \hline \multirow{2}{*}{ Total } & Number & 88 & 102 & 190 \\
\cline { 2 - 5 } & $\%$ & 46.32 & 53.68 & 100 \\
\hline
\end{tabular}

Pearson Chi-Square $=5.24943, \mathrm{df}=2, \mathrm{p}=0.072465$

Table 2. Descriptive analysis of the age of the respondents

\begin{tabular}{||c||c|c|c|c|c|c|c||}
\hline Gender & $\begin{array}{c}\text { No of } \\
\text { people }\end{array}$ & $\begin{array}{c}\text { Average value } \\
\text { (Means) }\end{array}$ & $\begin{array}{c}\text { Standard deviation } \\
\text { (SD) }\end{array}$ & $\begin{array}{c}\text { Standard Error } \\
\text { (SE) }\end{array}$ & Median & Min & Max \\
\hline \hline Male & 88 & 58.05 & 6.143 & 1.255504 & 59 & 44 & 67 \\
\hline Female & 102 & 57.63 & 6.658 & 1.418532 & 59 & 44 & 67 \\
\hline Total & 190 & 57.82 & 6.426 & 0.944411 & 59 & 44 & 67 \\
\hline
\end{tabular}

Mann-Whitney U Test: $Z=0.262557, \mathrm{p}=0.792892$

Table 3. Descriptive analysis of the duration of medical therapy

\begin{tabular}{|c|c||c|c||c||}
\hline \multicolumn{2}{|c||}{ Duration of therapy } & \multicolumn{2}{c||}{ Gender } & \multirow{2}{*}{ Total } \\
\cline { 2 - 5 } & & Male & Female & \\
\hline \hline \multirow{2}{*}{$\mathbf{1 - 5}$ years } & Number & 15 & 21 & 36 \\
\cline { 2 - 5 } & $\%$ & 7.90 & 11.05 & 18.95 \\
\hline \hline \multirow{2}{*}{$6-10$ years } & Number & 39 & 40 & 79 \\
\cline { 2 - 5 } & $\%$ & 20.53 & 21.05 & 41.58 \\
\hline \hline \multirow{2}{*}{$\mathbf{1 1 - 1 5}$ years } & Number & 34 & 41 & 75 \\
\cline { 2 - 5 } & $\%$ & 17.89 & 21.58 & 39.47 \\
\hline \hline \multirow{2}{*}{$\mathbf{1 5}$ years } & Number & 88 & 102 & 190 \\
\cline { 2 - 5 } & $\%$ & 46.32 & 53.68 & 100 \\
\hline \hline \multirow{2}{*}{ Total } & Number & & & \\
\cline { 2 - 5 } & $\%$ & & & \\
\hline
\end{tabular}

Pearson Chi-Square $=5.48451, \mathrm{df}=2, \mathrm{p}=0.182760$

Fifteen $(7.90 \%)$ of the male respondents used therapy in duration of $1-5$ years, 33 (17.37\%) for 610 years, $29(15.26 \%)$ for $11-15$ years and 11 $(5.79 \%)$ for a period > 15 years, while 25 (13.16\%) of the female respondents used therapy in duration of $1-5$ years, $34(17.89 \%)$ for $6-10$ years, 32 $(16.84 \%)$ for a period of $11-15$ years and 11 $(5.79 \%)$ for a period $>15$ years.
No statistically significant difference was observed between male and female respondents in relation to the periods of prescribed treatment (Pearson Chi-Square $=5.48451, \mathrm{df}=2, \mathrm{p}=$ 0.182760).

An analysis of the average, minimum and maximum duration of medical therapy was 
performed on the entire sample of 190 included respondents (Table 4 ).

The average duration of the medical therapy of the male respondents was 9.99, SD 4.278, median 10.0, minimum 3 and maximum 19 years, and the average duration of treatment of the female respondents was 9.75, SD 4.556, median 9.0, minimum 2 and maximum 20 years.

Regarding the duration of treatment, there was no statistically significant difference between male and female respondents (Mann-Whitney $\mathrm{U}$ Test: $Z=0.151446 p=0.671781$ ).

The patients with primary open-angle glaucoma were prescribed daily treatment with Timolol $0.5 \%$ and Brinzolamide every 12 hours and prostaglandins (Xalatan) every 24 hours, one drop in the glaucomatous eye. This means that patients with monocular glaucoma used one vial per month, whereas patients with binocular glaucoma used 1.2 vials in form of drops. Depending on the clinical picture, patients were prescribed artificial tears, antibiotics, vitamins and other medications, which increased the monthly medication costs by an additional $10-20 \%$. The monthly costs for medical therapy are shown in Table 5.

The monthly costs for the medical therapy of people with monocular primary open-angle glaucoma were 19.4-25.8 Euros, whereas for people with binocular glaucoma were 23.3-26 Euros. The respondents who were entitled to co-payment the monthly costs for medical therapy for monocular glaucoma were 12.1-17.2 Euros, and for binocular glaucoma 14.3-20.5 Euros.

Depending on the vocational education, occupation and work place, the respondents earned different personal income monthly: low personal income/235 Euros, average/up to 420 Euros and high personal income/over 421 Euros, and the analysis of the monthly personal income with reference to gender is shown in Table 6.

Table 4. Descriptive analysis of the duration of therapy of the entire sample of respondents

\begin{tabular}{||c||c|c|c|c|c|c|c||}
\hline \hline Gender & $\begin{array}{c}\text { No of } \\
\text { people }\end{array}$ & $\begin{array}{c}\text { Average value } \\
\text { (Means) }\end{array}$ & $\begin{array}{c}\text { Standard deviation } \\
\text { (SD) }\end{array}$ & $\begin{array}{c}\text { Standard Error } \\
\text { (SE) }\end{array}$ & Median & Min & Max \\
\hline \hline Male & 88 & 9.99 & 4.278 & 1.255504 & 10.0 & 3 & 19 \\
\hline Female & 102 & 9.75 & 4.556 & 1.418532 & 9.0 & 2 & 20 \\
\hline Total & 190 & 9.86 & 4.430 & 0.944411 & 9.0 & 2 & 20 \\
\hline
\end{tabular}

Mann-Whitney U Test: $Z=0.151446, p=0.671781$

Table 5. Monthly costs for medical therapy

\begin{tabular}{||l||c|c||}
\hline \multicolumn{1}{|c|}{ Type of Medicine } & Monocular glaucoma/Euro & Biocular glaucoma/Euro \\
\hline \hline Timolol & $1.7-2.5^{*}$ & $2-3^{*}$ \\
\hline Brinzolamide & $7-7.5^{*}$ & $8.4-9^{*}$ \\
\hline Prostaglandins (Xalatan, Travatan) & $7.5-11.5^{* *}$ & $9-13.8^{* *}$ \\
\hline Other medication & $3.2-4.3^{* *}$ & $3.9-4.3^{* *}$ \\
\hline Total & $19.4-25.8$ & $23.3-26$ \\
\hline
\end{tabular}

* - patients pay $20 \%+$ VAT, and the co-payment is $80 \%$

$* *$ - patients pay $100 \%$

$* * *$ - the ophthalmological examination is 10 Euros. Patients pay $10 \%$

Table 6. Descriptive analysis of the monthly personal income of the respondents

\begin{tabular}{|c|c||c|c||c||}
\hline \multirow{2}{*}{ Monthly income } & \multicolumn{2}{c||}{ Gender } & \multirow{2}{*}{ Total } \\
\cline { 3 - 5 } & & Male & Female & \\
\hline \hline \multirow{2}{*}{ Low income/235 Euros } & Number & 31 & 34 & 65 \\
\cline { 2 - 5 } & $\%$ & 16.32 & 17.89 & 34.21 \\
\hline \hline \multirow{2}{*}{ Average income/420 Euros } & Number & 35 & 42 & 77 \\
\cline { 2 - 5 } & $\%$ & 18.42 & 22.11 & 40.53 \\
\hline \hline \multirow{2}{*}{ High income/ > 421 Euros } & Number & 22 & 26 & 48 \\
\cline { 2 - 5 } & $\%$ & 11.58 & 13.68 & 25.26 \\
\hline \hline \multirow{2}{*}{ Total } & Number & 88 & 102 & 190 \\
\cline { 2 - 5 } & $\%$ & 46.32 & 53.68 & 100 \\
\hline
\end{tabular}

Pearson Chi-Square $=2.55, \mathrm{df}=1, \mathrm{p}=0.1099$ 
Sixty-five (34.21\%) of the respondents earned low personal income, $77(40.53 \%)$, average personal income and 48 (25.26\%) earned high personal income.

The economic burden on the monthly personal income borne by the respondents' costs for medical therapy was also calculated (Table 7).

The economic burden caused by the medical costs for the therapy, depending on the price and type of medication, participated with $8.72-16.81 \%$ in the monthly personal income of people with monocular glaucoma, whereas with binocular glaucoma 10.26-19.32\% and was statistically significantly higher when compared to the costs of highincome earners (Pearson Chi-Square $=9.1722$, df $=$ $2, p=0.028986)$.
Depending on the clinical stage and severity of the disease, the lost visual acuity reflected on the productivity and quality of the work performed by the respondents, and consequently, some of them were reassigned to lower positions and received lower monthly income, and the results of those tests are shown in Table 8.

The economic implications/burden on the monthly personal income was typically manifested by lower personal income and reduced income due to productivity loss, with statistically significant importance in the third clinical stage after $11-15$ years (Pearson Chi-Square $=9.97, \mathrm{df}=2, \mathrm{p}=0.0161$ ) and in the fourth clinical stage after more than 15 years from the diagnosis and treatment of the disease (Pearson Chi-Square $=9.41$, df $=2, \mathrm{p}=$ $0.0180)$, in relation to the other clinical stages.

Table 7. Economic burden on the monthly personal income of the respondents

\begin{tabular}{||l|c|c||}
\hline \multicolumn{1}{|c|}{ Monthly income } & Monocular glaucoma/\% & Biocular glaucoma/ \% \\
\hline \hline Low income/235 Euros & $8.72-16.81 \%$ & $10.26-19.32 \%$ \\
\hline Average income/420 Euros & $4.88-9.40 \%$ & $5.74-10.81 \%$ \\
\hline High income/ > 421 Euros & $<4.1-7.9 \%$ & $<4.82-9.08 \%$ \\
\hline
\end{tabular}

Pearson Chi-Square $=9.1722, \mathrm{df}=2, \mathrm{p}=0.028986$

Table 8. Economic implications for monthly personal income

\begin{tabular}{|c|c|c|c|}
\hline \multirow{2}{*}{\multicolumn{2}{|c|}{ Clinical stage }} & \multicolumn{2}{|c|}{ Economic implications } \\
\hline & & \multirow{2}{*}{$\begin{array}{c}\text { Reduced personal income } \\
0\end{array}$} & \multirow{2}{*}{$\begin{array}{c}\text { Loss of productivity } \\
0\end{array}$} \\
\hline 1-5 vears & Number & & \\
\hline $1-5$ years & $\%$ & 0 & 0 \\
\hline \multirow{2}{*}{ 6-10 years } & Number & 3 & 5 \\
\hline & $\%$ & 1.58 & 2.63 \\
\hline \multirow{2}{*}{$11-15$ years } & Number & 16 & 19 \\
\hline & $\%$ & 8.42 & 10 \\
\hline \multirow{2}{*}{$>15$ years } & Number & 22 & 25 \\
\hline & $\%$ & 11.58 & 13.16 \\
\hline \multirow{2}{*}{ Total } & Number & 41 & 49 \\
\hline & $\%$ & 21.58 & 25.79 \\
\hline
\end{tabular}

Pearson Chi-Square $=9.97, \mathrm{df}=2, \mathrm{p}=0.0161 ;$ Pearson Chi-square $=9.41, \mathrm{df}=2, \mathrm{p}=0.0180$

Table 9. Economic implications generated by therapy costs

\begin{tabular}{|c|c||c|c||c||}
\hline \multicolumn{2}{|c||}{ Economic implications } & \multicolumn{2}{c||}{ Gender } & \multirow{2}{*}{ Total } \\
\cline { 3 - 5 } & & Male & Female & \\
\hline \hline \multirow{2}{*}{ Burden on the family budget } & Number & 19 & 21 & 40 \\
\cline { 2 - 5 } & $\%$ & 10 & 11.05 & 21.05 \\
\hline \hline \multirow{2}{*}{ Inadequate treatment } & Number & 23 & 26 & 49 \\
\cline { 2 - 5 } & $\%$ & 12.11 & 13.68 & 25.79 \\
\hline \hline \multirow{2}{*}{ Total } & Number & 42 & 47 & 89 \\
\cline { 2 - 5 } & $\%$ & 22.11 & 24.73 & 46.84 \\
\hline
\end{tabular}

Pearson Chi-Square $=2.935, \mathrm{df}=2, \mathrm{p}=0.0988$ 
Due to the low personal income and the impact of the high medical costs for the therapy on the monthly personal budget, the economic burden caused by the medical costs on certain patients negatively impacted their family budget or due to economic reasons, they were treated inadequately with cheaper alternative medications or with lower therapeutic dose (Table 9).

In 40 respondents, the medical costs for the therapy burdened the family budget, and 49 respondents, due to high medical costs and economic reasons, were treated inadequately using cheaper alternative medications or lower doses of the therapy. The statistical analysis showed that in relation to these two economic indicators, there was no significant difference between the respondents of both genders (Pearson Chi-Square $=2.935$, df $=2$, $\mathrm{p}=0.0988)$.

\section{Discussion}

The pharmacoeconomic burden of primary glaucoma arises from the cost of medication, laser and surgical therapy, and inpatient treatment (13, 14).

The medical therapy includes administration of various groups of antiglaucoma medications: beta blockers, miotics, carbonic anhydrase inhibitors, alpha 2 agonists, prostaglandin analogues, neuroprotective, multivitamin and more than 15 other types of medication $(23,24,25,26,27)$.

The application of laser therapy generates the lowest costs for treatment of glaucoma compared to other types of treatments and at the same time gives the greatest comfort and quality of life, especially to people who are educated and adhere to a hygienic-diet regime in accordance with the vision condition, because after its application, the following 5-7 years, there is no need for prescription medication $(28,29)$.

The economic burden of the medical treatment for glaucoma to date is almost identical to the cost of surgical treatment, but due to the uncertain prognosis from surgery, the studies conducted in European countries indicate that in practice, the most effective way to treat glaucoma is with therapy of newer generation of anti-glaucoma medications, regardless of the fact that the economic burden of this treatment is very high, because it is lifelong (30, $31,32)$.

Varma R., Grekova D., Sarenac V.T., Lam B.L. and others indicate that the economic, individual and social burden in the advanced clinical stages of glaucoma is progressively increasing, when compared to the cost of treatment in the initial clinical stage of the disease $(20,33,34,35)$.

In the scientific studies conducted by Bagnis A., Hirsch JD. and others, it was determined that medical costs of the glaucoma patients treated with medical therapy accounted for 42 to $56 \%$ of total direct medical costs and that the economic costs of glaucoma treatment were directly correlated with the clinical stage in which they were treated and that the same, as the disease progressed, continued to further increase $(36,37)$.
Traverso C.E. and associates, in the analysis of the economic burden on glaucoma patients in European countries, say that the costs for glaucoma patients in the early stages are 455, and in the advanced stages of the disease - 969 Euros, while in a similar study in the US, they report that the cost of treatment of glaucoma in the early stages is 625 , and in the advanced stages, 2,511 Dollars, and annually from the budget, for the treatment of glaucoma, 2.5 billion dollars are allocated, of which 1.9 billion dollars are allocated to direct medical costs (38).

A retrospective study in Mexico, 462 hospitalized glaucoma patients found that the cost of hospital treatment was very high and the direct medical costs for one-month treatment accounted for $49.8 \%$ of monthly budget of the patients with average personal income, while the costs in lowincome patients were $61 \%$ (39).

In India, in a scientific study of glaucoma patients with low-income in urban areas (New Delhi) the direct medical costs for hospital treatment accounted for $18.4 \%$ of the monthly budget, and for hospital treatment in rural areas, the cost was 41.9\% (40).

A study on the economic burden of glaucoma conducted in Denmark, Germany, Italy, England, Ireland, France and Spain states that the economic burden on social communities and individuals is immense, and in terms of social cost, it varies from 11,758 to 19,111 Euros, and annual direct medical costs of the individuals ranged from 429 to 523 Euros, while the individual burden from productivity loss was between 7,436 and 10,200 Euros (41).

A study on individual productivity loss leading to lower-income was conducted in the United States in 2004. It included 125,882 visually impaired and 40,671 blind people, including glaucoma patients. It was reported that the visually impaired received lower annual income of $\$ 9,851$ and the blind people received $\$ 12,121$ less, compared to people with normal vision, with a total loss of more than $\$ 1.7$ billion (42).

Analyzing the productivity losses and monthly income of people with primary glaucoma in the Mexican state of River, Gomez found that $61.5 \%$ of glaucoma patients earned low personal income, $19.5 \%$ average personal income, $7.9 \%$ high personal income, while others did not earn any personal income (38). Similar results were found by Nayak B with associates in India, confirming that hospitalized primary glaucoma patients earned lower personal income when compared to other hospitalized people $(39,40)$.

\section{Conclusion}

Primary open-angle glaucoma generates a significant individual and social economic burden as a consequence of direct and other medical costs during treatment and indirect losses from reduced productivity as a result of visual impairment.

Pharmacoeconomic costs depend on the type of medication, the doctrines applied, their prices and the length of therapy, and in our research they amount to 20.5-39.5 Euros for monocular glaucoma, 
while 24.1-45.4 Euros per month for binocular glaucoma.

Due to the reduced productivity and nonfulfillment of work obligations, 34.21\% received low personal income, whereas $25.26 \%$ high personal income. Among the respondents with low personal income with monocular glaucoma, the costs for medications in the monthly personal income participated with $8.72-16.81 \%$, while with binocular glaucoma $10.26-19.32 \%$. The share of the medication costs of respondents with high personal income was of much lower proportion, and for monocular glaucoma it was $<4.1-7.9 \%$, while for binocular glaucoma it was $<4.82-9.08 \%$.

The disproportion between the increased medical costs and the indirect losses due to the reduced income was reflected in existential endangerment and social family burden in $21.05 \%$, whereas
$25.79 \%$ of the respondents were treated inadequately with generic alternative medications or with inadequate dose of medications for economic reasons.

Productivity losses due to decreased work ability (WAI - Work ability index) which was 10-30\% were recorded in $25.79 \%$, while in $21.58 \%$ of the respondents, due to non-fulfillment or poor performance of tasks, were demoted to a lower position or received a reduced monthly personal income.

The use of screening programs for early detection and timely diagnosis, availability of medications, regular ophthalmological examinations and adequate treatment, will prevent the progression of the disease, vision loss and will help preserve the work ability, thus reducing individual social and economic losses and will improve the quality of life of glaucoma patients.

\section{References}

1. Cvetković D. Oftalmologija, udžbenik za studente medicine. Beograd (SRB): CIBID; 2010.

2. Casson RJ, Chidlow G, Wood JP, Crowston JG, Goldberg I. Definition of glaucoma: clinical and experimental concepts. Clin Experiment Ophthalmol 2012; 40(4):341-9. [CrossRef] [PubMed]

3. Flammer J. Glaucoma. $2^{\text {nd }}$ ed. Toronto (CA): 2003.

4. Shields MB, Ritch R, Krupin T. Classifications of the glaucomas. In: Ritch R, Shields MB, Krupin T, editors. The glaucomas. $2^{\text {nd }}$ ed. St Louis: Mosby; 1996.

5. Janev K. Opšta oftalmologija. Skopje: Menora; 2002.

6. Prum BE, Rosenberg LF, Gedde SJ, Mansberger SL, Stein JD, Moroi SE, et al. Primary Open-Angle Glaucoma Preferred Practice Pattern Guidelines. Ophthalmology 2016;123(1):41-111. [CrossRef] [PubMed]

7. Chen XY, Cai Y. Epidemiology and classification of primary angle-closure glaucoma today Zhonghua Yan Ke Za Zhi 2011;47(10):949-52. [PubMed]
8. Cook, C, Foster, P. Epidemiology of glaucoma: what's new? Can j ophthalmol 2012;47:3.

[CrossRef] [PubMed]

9. Geimer SA. Glaucoma diagnostics. Acta Ophthalmol 2013;91(1):1-32. [CrossRef] [PubMed]

10. Rudnicka AR, Mt-Isa S, Owen CG, Cook DG, Ashby D. Variations in Primary Open-Angle Glaucoma Prevalence by Age, Gender, and Race: A Bayesian MetaAnalysis. IOVS 2006;47:4254-61. [CrossRef] [PubMed]

11. Rein DB, Zhang $P$, Wirth KE. The economic burden of major adult visual disorders in the United States. Arch Ophthalmol 2006;124:1754-60. [CrossRef] [PubMed]

12. Burr JM, Mowatt G, Hernández R, Siddiqui MAR, Cook $\mathrm{J}$, Lourenco $T$, et al. The clinical effectiveness and cost-effectiveness of screening for open angle glaucoma: a systematic review and economic evaluation. Health Technol Assess 2007;11(41):1-190. [CrossRef] [PubMed] 
13. Feiner L, Piltz-Seymour J. Collaborative initial glaucoma treatment study: a summary of results to date. Curr Opin Ophthalmol 2003;14:106-11. [CrossRef] [PubMed]

14. Bagnis A, Papadia M, Scotto R, Traverso CE. Current and emerging medical therapies in treatment of glaucoma. Expert Opin Emerg Drugs 2011;16(2):293307. [CrossRef] [PubMed]

15. FZO/RSM, Skopje, 2020.

16. MF/RSM, Skopje, 2020.

17. PIOM/RSM, Skopje, 2020.

18. VanNewkirk MR, Weih L, McCarty CA, Stanislavsky YL, Keeffe JE, Taylor HR. Visual impairment and eye diseases in elderly institutionalized Australians. Ophthalmology 2000;107:2203-8. [CrossRef] [PubMed]

19. Cooney J, Landers G, Rein D, Bae J, Curry R. Comparative Assessment of Cost and Care Outcomes Among Georgia's Community-Based and FacilityBased Longterm Care Programs. Atlanta. Georgia State University 2004.

20. Varma R, Lee P, Goldberg I, Kotak S. An Assessment of the Health and Economic Burdens of Glaucoma. Am J Ophthalmol 2011;152:515-22. [CrossRef] [PubMed]

21. WHO. WHO methods and data sources for global burden of disease estimates 2000-2011. Geneva: World Health Organization. 2013.

22. de Zwart BC, Frings-Dresen MH, van Duivenbooden JC. Test-retest reliability of the Work Ability Index questionnaire. Occuop Med 2002;52(4):177-81. [CrossRef] [PubMed]

23. Babić N. Medikamentozna terapija glaukoma. Novi Sad (SRB): Medicinski fakultet Univerziteta u Novom Sadu 2013;5-6.

24. Servat JJ, Bernardino CR. Effects of common topical antiglaucoma medications on the ocular surface, eyelids and periorbital tissue. Drugs Aging 2011; 28(4):267-82. [CrossRef] [PubMed]

25. Rachmiel R, Trope GE, Chipman ML, Gouws P, Buys YM. Effect of medical therapy on glaucoma filtration surgery rates in Ontario. Arch Ophthalmol 2006; 124(10):1472-7. [CrossRef] [PubMed]

26. Kang JH, Loomis SJ, Wiggs JL, Willett WC, Pasquale LR. A prospective study of folate, vitamin B6, and vitamin B12 intake in relation to exfoliation glaucoma or suspected exfoliation glaucoma. JAMA Ophthalmology 2014;132(5): 549-59. [CrossRef] [PubMed]

27. Vasudevan SK, Gupta V, Crowston JG. Neuroprotection in glaucoma. Indian J Ophthalmol 2011; 59:102-13. [CrossRef] [PubMed]

28. Stein JD, Kim DD, Peck WW, Giannetti SM, Hutton DW. Cost-effectiveness of medications compared with laser trabeculoplasty in patients with newly diagnosed open-angle glaucoma. Arch Ophthalmol 2012;130(4): 497-505. [CrossRef] [PubMed]
29. Babighian S, Caretti L, Tavolato M, Cian R, Galan A. Excimer laser trabeculotomy vs 180 degrees selective laser trabeculoplasty in primary open-angle glaucoma. A 2-year randomized, controlled trial. Eye 2010;24 (4):632-8. [CrossRef] [PubMed]

30. Schmier JK, Halpern MT, Jones ML. The economic implications of glaucoma: a literature review. Pharmacoeconomics 2007;25(4):287-308.

[CrossRef] [PubMed]

31. Omoti AE, Edema OT, Akpe BA, Musa P. Cost analysis of medical versus surgical management of glaucoma in Nigeria. J Ophthalmic Vis Res 2010;5(4):232-9. [PubMed]

32. Rahman MQ, Beard SM, Discombe R, Sharma R, Montgomery DM. Direct healthcare costs of glaucoma treatment. Br J Ophthalmol 2013;97(6):720-4. [CrossRef] [PubMed]

33. Grekova DD, Andreevska KG, Petrova G, Petkova V. Assessment of the social and economic burden of glaucoma in Bulgaria 2018. [CrossRef]

34. Sarenac Vulovic T, Janicijevic K. Primary open-angle glaucoma and farmacoeconomics - review. Sanamed 2016;11(3):243-8. [CrossRef]

35. Lam BL, Zheng DD, Davila EP. Trends in glaucoma medication expenditure: Medical Expenditure Panel Survey 2001-2006. Arch Ophthalmol 2011;129: 1345-50. [CrossRef] [PubMed]

36. Bagnis A, Papadia M, Scotto R, Traverso CE. Current and emerging medical therapies in treatment of glaucoma. Expert Opin Emerg Drugs. 2011;16(2):293307. [CrossRef] [PubMed]

37. Hirsch JD. Considerations in the Pharmacoeconomics of Glaucoma. Manag Care 2002;11(11suppl):32-7. [PubMed]

38. Traverso CE, Walt JG, Kelly SP. Direct costs of glaucoma and severity of the disease: a multinational long term study of resource utilisation in Europe. $\mathrm{Br}$ ] Ophthalmol 2005;89(10):1245-9. [CrossRef] [PubMed]

39. Gabriel Lazcano-Gomez, de los Angeles M, Cadena R, Torres-Tamayo M, Hernandez de Oteyza A, TuratiAcosta M, Jimenez-Román J. Cost of glaucoma treatment in a developing country over a 5 -year period. Medicine 2016;95:47. [CrossRef] [PubMed]

40. Nayak B, Gupta S, Kumar G. Socioeconomics of longterm glaucoma therapy in India. Indian J Ophthalmol 2015;63:20-4. [CrossRef] [PubMed]

41. Poulsen PB, Buchholz P, Walt JG, Christensen TL, Thygesen J. Cost analysis of glaucoma-related-blindness in Europe. 2005. [CrossRef]

42. National Center for Health Statistics. National Hospital Ambulatory Medical Care Survey, Outpatient Department File. 2006. [PubMed] 


\title{
FARMAKOEKONOMSKE IMPLIKACIJE GENERISANE OD STRANE PRIMARNOG GLAUKOMA OTVORENOG UGLA KOD RADNIKA
}

\author{
Zoran Velkovski ${ }^{1}$, Maja Belevska², Emilija Gjosevska Dastevska ${ }^{3,4}$
}

\begin{abstract}
${ }^{1}$ Klinička bolnica Bitolj, Odeljenje za laboratorijsku dijagnostiku, Bitolj, Severna Makedonija ${ }^{2}$ Klinička bolnica Bitolj, Odeljenje za oftalmologiju, Bitolj, Severna Makedonija

${ }^{3}$ Medicinski fakultet Skoplje, Klinika za očne bolesti, Skoplje, Severna Makedonija

${ }^{4}$ Klinika za očne bolesti, Skoplje, Severna Makedonija
\end{abstract}

Kontakt: Zoran Velkovski

Partizanska bb, 7000 Bitola, Severna Makedonija

E-mail: zoranv_mk@yahoo.com

Glaukom je optička neuropatija, koja zbog ireverzibilnog gubitka vidne oštrine, direktnih i drugih medicinskih rashoda povezanih sa lečenjem i indirektnih gubitaka, usled smanjene produktivnosti, generiše socijalno i farmakoekonomsko opterećenje kod obolelih osoba. Cilj rada bio je da se sagledaju farmakoekonomske implikacije generisane od strane primarnog glakoma otvorenog ugla kod radnika različitih profesija. Rad predstavlja studiju preseka sa kvantitativnim analitičkim pristupom (cross sectional study), u koju je uključeno 190 osoba muškog i ženskog pola, starosti od 38 do 67 godina, sa primarnim glaukomom otvorenog ugla, sa očuvanom oštrinom vida > 6/18 (0,33), prema klasifikaciji ICD-10, sprovedenoj u periodu avgust - novembar 2020. godine, na teritoriji Severne Makedonije. $34,21 \%$ ispitanika zarađivalo je minimalni, $40,53 \%$ prosečni, a $25,26 \%$ visok lični dohodak. Farmakološki rashodi lečenja biokularnog glaukoma iznosili su od 24,1 evro do 45,4 evra mesečno, koji učestvuju sa $10,26 \%-19,32 \%$ kod osoba sa minimalnim i $<4,82 \%-9,08 \%$ kod osoba sa visokim mesečnim ličnim dohotkom. U 21,05\% slučajeva ekonomsko opterećenje manifestovalo se egzistencijalnom ugroženošću porodice, a 25,79\% ispitanika, iz ekonomskih razloga, lečilo se neadekvatnim generičkim, alternativnim lekovima ili neadekvatnim dozama. Gubitak produktivnosti registrovan je kod $25,79 \%$ ispitanika, a njih $21,58 \%$, zbog neispunjavanja radnih obaveza, zarađivalo je smanjeni lični dohodak. Glaukom generiše ogroman farmakoekonomski teret, koji je posledica direktnih i drugih medicinskih rashoda lečenja $\mathrm{i}$ indirektnih gubitaka zbog smanjene produktivnosti, što zahteva primenu skrining programa za pravovremenu dijagnozu i adekvatnu, redovnu oftalmološku terapiju, koja će doprineti održavanju oštrine vida i radne sposobnosti, a time će se smanjiti i farmakoekonomsko opterećenje obolelih.

Acta Medica Medianae 2021;60(3):11-19.

Ključne reči: primarni glaukom, farmakoekonomske implikacije, terapija, rashodi, smanjenje produktivnosti 